\title{
U2AF1 Gene Mutation
}

National Cancer Institute

\section{Source}

National Cancer Institute. U2AF1 Gene Mutation. NCI Thesaurus. Code C133700.

A change in the nucleotide sequence of the U2AF1 gene. 